\title{
A Reconquista Cristã Portuguesa e a Reordenação Muçulmana: o Uso dos Forais como Modelo de Submissão e o Controle Régio nos Séculos XII a XV
}

The Portuguese Christian Reconquest and the Muslim Reordering: the Use of Charters as a Model of Submission and Royal Control in the 12th to 15th Centuries

Andréa Alvares da Cunha ${ }^{1}$

James Eduard Campos e Sant'anna²

${ }^{1}$ Professora, Mestra em História Antiga e Medieval pelo PGHIS-UFF [área de concentração História Islâmica] e lecionando na SEEDUC-RJ. E-mail mudajjan@gmail.com.

${ }^{2}$ Sheikh e Delegado Internacional da CIMS -Conveiyng Islamic Message Society, Acadêmico de Direito na Faculdade Marechal Rondon - Universidade Nove de Julho. E-mail: yunusmustafa999@gmail.com.

Recebido em 29 de março de 2021; Aceito em 30 de junho de 2021.

DOI: $10.12957 /$ nearco.2021.58782

\section{Resumo}

Com o processo político denominado por Reconquista Cristã, ocorrida na Península Ibérica entre os séculos XII a XIII, a população muçulmana acaba sendo reorganizada espacialmente e politicamente na área portuguesa através de um conjunto de práticas baseadas na Legislação Regia, iniciando-se com a emissão dos Forais, sendo o marco de sua sujeição futura e alteridade como 'elemento infiel' no decorrer das centúrias seguintes.

Palavra-chaves: Reconquista; Islam; Forais; Direito.

\begin{abstract}
With the political process called Christian Reconquest, which took place in the Iberian Peninsula between the 12th and 13th centuries, the Muslim population ended up being spatially and politically reorganized in the Portuguese area through a set of practices based on the Regia Legislation, starting with the issuance of Forais, being the mark of his future subjection and alterity as an 'infidel element' during the following centuries.
\end{abstract}

Keywords: Reconquest; Islam; Charters; Right. 


\section{Introdução}

Este artigo foi alicerçado a partir da análise e estudo das fontes normativas regias portuguesas, período medieval e moderno, que versam sobre as mais variadas formas de controle e submissão das comunas mouras ou 'mourarias' no reino luso, pós Reconquista cristã nos séculos XII ao XV, centrando-se na análise dos documentos normativos denominados por 'Forais', como o foco principal da sujeição, suspeição e controle das comunidades muçulmanas remanescentes no reino português pós reconquista.

Objetivamos evidenciar no presente artigo a importância do uso desta legislação como meio principal para a sujeição, subordinação e a suspeição dos elementos muçulmanos representados pelas suas comunidades ou comunas ditas 'mouras', aos desígnios régios para a completa centralização do Estado, sendo normatizada e explorada, estereotipada e ainda, alienada de sua própria identidade islâmica.

\section{Desenvolvimento}

O processo de Reconquista Cristã na Península Ibérica compreende as relações entre os estados cristãos e os muçulmanos e a evolução de seus poderios miliares e de conquistas territoriais, onde vemos a ação de geoestratégia portuguesa bastante similar à realizada pela Coroa de Leão e Castela voltando-se para a captura de locais ao longo de vales, de grande penetração cultural e áreas férteis e que por isso, eram economicamente importantes. Neste interim, vemos a pesada atuação das ordens miliares-religiosas no processo de "retomada" e conquista das áreas priorizadas pelos reinos cristãos, caso como a ordem de Santiago, baseada no sul do Tejo e que será fundamental para a política de conquista portuguesa.

As cidades muçulmanas eram visadas devido ao seu papel de polarização comercial, com a grande circulação de homens, ideias, armas, cavalos e insumos além de serem consideradas áreas de produção cultural e tecnológica, direcionando os seus centros urbanos para as grandes rotas magrebinas - portos norte-africanos de Ceuta, 
Alexandria, Alepo, Fez, Marrakesh, Cairo, Makkah e, também, Bagdah (COELHO, 1986). Temos assim a cobiça sobre as suas variadas formas de produção citadina e das áreas de seu termo, onde criava-se o gado e plantavam-se os mais variados produtos hortícolas e cerealíferos além da produção de azeite e açúcar como podemos ver na descrição:

\begin{abstract}
O Andaluz tem sido comparado por muitos autores ao paraíso terreal [...] pois é bem conhecido que o paraíso perpétuo é aquele país em que a bolota, a avelã, a noz, a castanha e outros frutos dos climas nórdicos crescem juntamente com as bananas, o açúcar de cana e outros produtos que são próprios dos países quentes [...]. A cana-de-açúcar cresce em grande luxúria ao longo de toda a costa sudeste e, nas regiões mais temperadas, a banana e outros frutos deliciosos. Em geral, excepto tâmaras, que não medram, todos os frutos de cada clima podem ser encontrados em abundância (COELHO, 1989, p. 79).
\end{abstract}

No século XII veremos dessa maneira a ação cristã da nobreza senhorial portuguesa no processo de Reconquista, sendo liderada pela família do príncipe D. Afonso Henriques [nobreza nortenha], oriunda do condado Portucalense, onde vemos a sua constituição pública e política como 'rex portugalensis' com as conquistas sobre os muçulmanos e assim, fortalecendo-se na disputa de poder entre reinos cristãos, como as disputas com o reino de Leão e Castela.

Sendo o conquistador de terras mouras, combatendo o "infiel" e legitimando terras para a nobreza e a população cristã, fundamentariam sua imagem de "rex" na ideia de conquista e submissão, subjugação de elementos estranhos, de "usurpadores" de terras cristãs que sendo reconquistadas Ihes confeririam assim, a legitimidade necessária para a exploração das mesmas e a ampliação de seus domínios senhoriais e vassálicos. ${ }^{38}$ D. Afonso Henriques e sua família deixariam de ser meros caudilhos da

38A questão da participação dos cavaleiros da baixa nobreza e os cavaleiros vilãos nortenhos advinham da necessidade premente de conquistarem os escravos mouros, que eram equiparados em preços de mercado ao valor do gado asinino, além de buscarem gêneros cerealíferos e demais alimentícios, armas e cavalos adextrados ou não, o que eram de suma importância para o mundo da guerra senhorial. Os mouros eram também usados além de escravos citadinos, como colonos em herdades, em áreas de repovoamento. CUNHA, Andrea Alvares da. Aos meus mouros forros de Lixboa'. Identidade, dependência e hierarquia nas comunidades muçulmanas do reino de Portugal (séculos XII ao XV). Dissertação de mestrado apresentada ao curso de Pós graduação em Historia da Universidade Federal Fluminense, Rio de Janeiro, Niteroi, 2005. 
nobreza nortenha, mas investidos da 'nobilitas' e da 'strenuitas' estariam dignificados como reis, pela capacidade de conquista e de domínio das comunidades muçulmanas, ampliando a área de seus domínios e, consequentemente da Santa Sé, necessária como a sua legitimadora de conquistador e de realeza.

Com o processo da Reconquista Portuguesa, vemos a legitimação de D. Afonso Henriques e de sua dinastia, como 'rex portugalensis' e isso se dá principalmente após a conquista da cidade de Coimbra em 1131 - cidade escolhida como sua base espiritual e mítica [ de um topos régio] sendo ligada aos centros monásticos poderosos, e promovendo o estreitamento político entre a realeza e a Igreja, através da atuação do Mosteiro de Santa Cruz de Coimbra e, o de Alcobaça, locais onde encerravam os túmulos e a memória de seus antepassados (MATTOSO, 1986).

As guerras de reconquista eram diferentes das conhecidas 'razzias' das milicias concelhias, pois eram voltadas para a apropriação régia das áreas e pontos nevrálgicos, pólos e rotas comerciais de forma a estabelecerem a partilha entre os poderes régio e os senhoriais laicos e eclesiásticos - estes expressos pelas ordens seculares, as ordens regulares e as militares-religiosas. Temos assim, a instituição de uma forma de polarização e controle das áreas e cidades conquistadas constituindo um 'sistema nervoso central' que englobava as redes de circuitos citadinos das cidades que se estendiam até a costa atlântica indo de Valença até Silves, passando por Guimarães, Porto, Aveiro, Coimbra, Leiria, Santarém, Lisboa, Alcácer do Sal, Beja e Évora.

A partir deste núcleo central das cidades reconquistadas, implementou-se então uma forma e governo que promovesse o total controle das áreas e das populações, como um modelo para as demais conquistas subsequentes e como meio de centralização régia via administração pública, com a articulação dos poderes senhoriais nas áreas controladas. Uma das mais importantes ações, voltadas para a reestruturação do espaço público reordenado de acordo com a política cristã da nascente realeza portuguesa, se deu através da manipulação do elemento muçulmano que não perecendo sob as espadas cristãs, foram sendo reordenados nos senhorios e herdades, e caracterizados judicialmente e legalmente como 'mouros', e ainda 'mouros do rei' independentemente de sua identidade étnica, social, política e econômica ficando 
restritos a uma única condição jurisprudencial, isenta de direitos e explorados pelos senhorios que compunham a égide do poder medieval no reino português em ascensão.

O elemento muçulmano presente nas terras ibéricas não era apenas um praticante da fé islâmica em um determinado local, mas sim um indivíduo com sua identidade política, social e cultural, pois ser muçulmano não é algo que se restringe exclusivamente a prática de fé, mas com o processo da Reconquista, foram reduzidos social, cultual e politicamente ao termo 'mouro'. Dessa forma temos grupos distintos como andaluzes, árabes, berberes, muladis ou neomuçulmanos, muçulmanos brancos ou negros, agora determinados juridicamente apenas como 'mouro' (CUNHA, 2005).

Sob o estatuto de vencidos, eram submetidos ao serviço dos vencedores, que se aproveitavam das vantagens materiais, dos conhecimentos técnicos, da organização material e exploram o mouro pelo trabalho, impondo à sua sociedade pouco à pouco, as suas práticas religiosas e morais e a sua concepção de mundo cristão a partir da convivência e de 'benesses políticas' à alguns elementos escolhidos pelo que poderiam proporcionar em uma troca de benefícios, que era voltado especificamente ao fortalecimento político cristão.

A ocupação cristã fomentou, ainda, as bases para o aprofundamento da "evangelização", que se concentrava especialmente no esforço de garantir a cobertura sacramental de todo território conquistado e de vigiar 'a pureza da fé' dos que conviviam com os mouros (e judeus), inculcando ainda, as práticas e a liturgia romana entre os que seguiam o ritual moçárabe. Partiam, para isso, do ideal de triunfo cristão dos que antes eram humilhados e, agora, eram vencedores pelo poder de Deus (MATTOSO, 1988).

Desde o século XII, são alocados pelos senhores em seus domínios para promover a expansão do povoamento, ou levados a trabalhar nas cidades, nos mesteres citadinos. A influência islâmica foi notável e determinante no domínio da tecnologia artesanal, nos setores de produção e de trocas, na da administração municipal e militar. São exímios também na vida ligada ao mar e na pecuária. Eram então procurados para o uso em todas as formas de atividades laborais, sejam urbanas ou rurais. 
Os cristãos se apoderam, com a Reconquista, não só das terras, mas também da cultura islâmica à qual se moldam, e constituem seu reino, aproveitando-se da estrutura já estabilizada, o que se verifica na permanência do uso dos vocábulos designativos árabes para as mais variadas atividades, ligadas 'construção civil (alicerce), metalurgia (almotoila, argola, aldraba, alfageme), ao sistema de pesos e medidas (almude, alqueire, arrátel, arroba, teiga, quintal), aos elementos do tecido urbano ou suburbano (arrabalde, azinhaga, chafariz, alcáçova, almedina, almuinha), aos objetos industriais e artífices relacionados ao abastecimentos citadino (alfândega, azémola, armazém, récua, almocreve, azemel, açougue). ${ }^{39}$

Os vocábulos marcavam ainda os designativos alimentares, sobretudo os que se referiam aos condimentos e a certos pratos presentes no cotidiano alimentício (adiafá, acepipe, acorda, açúcar, almôndega, açafrão, acelga, azeite), algumas plantas utilizadas medicinalmente, os produtos hortícolas e certas flores (açucena, alcachofra, alecrim, alface, alfarroba, alfazema, algodão, azambuja, laranja, limão) e a tecnologia de regadio e a moagem (acéquia, açude, alcatruz, azenha, nora, atafona) (MATTOSO, 1988, p. 327).

Para promover uma maior integração desta enorme população à sociedade cristã e, principalmente, ao contexto concelhio, os primeiros reis outorgaram os Forais, instrumentos de controle social e de tentativa de atribuir aos muçulmanos um lugar no interior do corpo da sociedade, evitando ainda a fuga da mão-de-obra ou sublevações.

O poder régio utiliza assim, os Forais, como um meio de subjugação e controle político-social da população muçulmana, ligando-as diretamente à casa régia como seus servos diretos, estabelecendo assim os vínculos de sua dependência, que vão perdurar até as centúrias subsequentes, ou seja, do século XII ao XV, quando são expulsos pelo rei D. Manuel I, o Venturoso.

\footnotetext{
${ }^{39} \mathrm{O}$ que podemos verificar como a sua marca cultural e social, que permeia até a atualidade na língua lusófona. Não podemos apagar a História de um grupo social que foi parte presente e atuante, independentemente de sua estigmatização como o 'outro, o infiel' . A dualidade da alteridade e de sua estigmatização encontra-se marcada também na gramática lusófona, onde os termos 'mouro', 'mourejar' designam o trabalho pesado, o trabalho escravo e a condição de baixo valor social. Conforme consulta https://www.dicio.com.br/mouro/ e ainda https://www.sinonimos.com.br/mouro/ data acesso: 28/03/2021.
} 
A partir daí, os muçulmanos passam a ser tratados prioritariamente como força motriz, ou seja, a força de trabalho que deveria ser regulamentada, controlada observada e ainda, como objeto que eram, comercializados como escravos ${ }^{40}$ (HEERS, 1983) ou como bens que eram herdados, controlados pelo viés municipalista que era ordenado pelos senhorios laicos, régios e os eclesiásticos - das ordens regulares como o caso do Mosteiro de Alcobaça e o Mosteiro de Coimbra, das seculares e os de caráter militar-religioso como a Ordem de Santiago, a do Templo entre outros (MARQUES, 1986, p. 316-317).

Os Forais tornam-se a principal forma ordenadora legal e municipalista do controle sobre a população muçulmana que permaneceu nas terras agora cristãs 'reconquistadas' e de acordo com o senhorio, eram tratados de maneiras diversificadas a partir da ótica de sua exploração e submissão, como o caso dos forais de modelo conimbricense [de Coimbra, 1111] que eram utilizados pela Ordem do Templo:

Se o mouro de alguém, andando solto, fizer calúnia, o seu senhor responderá por ele, segundo a calúnia que fizer, ou, então, seja entregue na mão do mordomo. O mordomo não se apodere de nenhum mouro que estiver vinculado, ou de qualquer moura solta, seja qual for a calúnia que fizer. Mas se $o$ alcaide e o concelho entenderem que fez tal coisa porque deva ser apedrejado ou cremado, seja apedrejado e cremado. No entanto, se o malefício for tal por que deva ser açoitado e punido corporalmente, seja-o, e depois entregue-se ao seu senhor (COELHO, 1996).

Este tipo de foral - filiado ao modelo do de Coimbra (1111), abrangendo os concelhos de Tomar, Ourém, Foz do Zêrere, Pombal, Terras Novas, Arega e Figueiró dos Vinhos - é um exemplo da organização de povoamento exercido pelas ordens militaresreligiosas, onde a mão-de-obra básica era a do escravo mouro, sujeita então às mais duras penalizações (como a pena de morte), para promover a ordo cristã e subjugar o 'infiel' ao poder da milícia de Cristo, e consequentemente, ao Papado.

\footnotetext{
${ }^{40}$ Ao longo dessas lutas pela Reconquista cristã até 1492, a guerra sarracena alimenta amplamente os mercados cristãos dos países mediterrânicos, sendo os cativos empregados de forma imediata em todos os tipos de ofícios, competindo inclusive com os operários assalariados ou os domésticos livres assoldados. Esses escravos capturados em guerras e razzzias eram comumente denominados por mouros. Cf HEERS, Jacques. Escravos e Domésticos na Idade Média. São Paulo, DIFEL, 1983. Pg. 23-24
} 
Segundo Caetano (CAETANO, 2000), os costumes eram a principal forma de direito vigente, neste mundo marcado pelas razzias e pela força da tradição, em maior parte residual das várias legislações que haviam vigorado anteriormente na Península: o direito romano, a legislação visigótica, os costumes muçulmanos e, por fim, os costumes estrangeiros oriundos das colônias que se estabeleceram com a Reconquista - caso das colônias dos cruzados (REIS, 2002).

Os costumes dividiam-se, então, em gerais e locais. Os costumes gerais dividiamse ainda em populares e os da corte. Os costumes gerais eram as práticas costumeiras que haviam se generalizado pela sua antiguidade e pela repovoação promovida pela reconquista, e que se aplicavam regularmente por todo o território, isso feito pela própria população na maioria das vezes. Eram considerados costumes gerais ainda os pleitos levados à Corte ou a El-Rey, devido ao seu caráter consuetudinário, como o que se estabelece com as 'façanhas'. ${ }^{41}$

Já os costumes locais eram aqueles praticados em uma determinada região, distrito ou povoação, de acordo com a interação entre a tradição oral e o conteúdo de antigas leis escritas. Ao serem compilados, formaram os costumes municipais ou foros, que eram dados pelos reis e senhorios laicos ou eclesiásticos juntamente com os Forais, ao fundarem novas povoações.

Já o Foral ou carta de foral era um diploma concedido pelo rei, por senhorios laicos ou eclesiásticos a uma determinada terra, contendo, assim, as normas que disciplinariam as relações dos povoadores ou habitantes entre si e destes com a autoridade outorgante. O Foral representa ainda uma das formas mais significativas das denominadas cartas de privilégio. Estas são mais amplas, já que designam todos os tipos de documentos que atribuem prerrogativas ou isenções de qualquer natureza, mas designam ainda para as novas ou comunidades especiais uma disciplina jurídica específica e mais favorável do que a vigente. (COSTA, 2002, p. 188-189)

\footnotetext{
${ }^{41}$ A 'façanha' era uma decisão régia (ou feita em nome do rei) sobre um determinado caso, que se tornava então um exemplo para os casos considerados de igual valor, formando assim na corte um costume jurisprudencial. Cf CAETANO, Marcello. Op cit, p. 233.
} 
Os forais distinguiam-se, assim, da seguinte forma: os forais originários e os forais confirmativos e ampliativos. Os forais designados como originários são documentos escritos, outorgados de forma unilateral pelo rei ou senhorio, que dispõe de uma certa área em benefício de uma coletividade, sendo considerado pelas partes acordadas como um pacto inviolável.

Seu principal objetivo é conceder a esse grupo de indivíduos, de forma vitalícia e hereditária, o domínio da área em questão, que deviam povoar, cultivar e defender como homens livres que já são ou que passarão a ser ao nelas ingressarem e, fazerem a justiça conforme delimitado pelo documento legal.

A concessão de terras é feita em caráter hereditário, fixando os encargos e as demais obrigações que a coletividade e seus membros têm com a autoridade outorgante, evitando o arbítrio ou exigências e garantindo os seus direitos sob a forma de privilégios, para que a fixação dos interesses comuns se torne algo concreto, fazendo surgir assim a identidade social desta coletividade. Os forais confirmativos ou ampliativos são, então, os vários forais que uma mesma localidade recebe - os últimos confirmam os primeiros - considerados os mais importantes.

Nas primeiras décadas do século XIV o termo 'foral' é usado de forma ampla e generalizada para designar os diplomas que até então apareciam apenas referidos como 'carta de foro', foro ou uma outra designação. Há uma popularização do termo foral, que passa a ser associado ao termo foro ou costumes antigos, o que se manifesta principalmente na exposição dos agravos diante das Cortes, nas quais o poder régio respondia 'mando que se guarde o costume antigo' ou 'verey a carta e farey o que devo'. 42

Em 1361, já aparecem as primeiras diferenciações entre os termos foro e foral, quando o foral passa a designar o documento que fixa um estatuto jurídico (mesmo sendo agora voltado para a característica econômica) com foro designando taxas ou rendas a pagar. Com isso, os forais acabam tendo sua principal função, a legislativa,

\footnotetext{
${ }^{42}$ Cf REIS, António Matos. Origens dos Municípios Portugueses. Lisboa, Livros Horizonte, 2002.
} 
esvaziada diante do crescimento do concelho, pois passam a ser mais limitados e ligados a enfiteuse e emprazamentos de modo geral, sendo então denominados por "carta de foro' ou 'foro'

Em alguns forais de concelhos rurais de fraca urbanização oferecia-se aos mouros e cristãos servos a 'ingenuitas', desde que eles se recolhessem aos limites jurisdicionais estipulados, passando a usufruir dos privilégios e deveres concedidos, como em Tavares (1114), Freixo (1152), Urros (1152), Torres de Moncorvo (1201) e Santa Maria (1284) (MARQUES, 1986, p. 324-327).

Os mouros, nestes forais, são presos de guerra, bens móveis disputados principalmente nos municípios no qual o movimento concelhio centra-se no povoamento empreendido pelas ordens militares-religiosas, como a Ordem do Templo, a Ordem de Santiago, a Ordem de Avis.

Em outros grupos de forais, como o grupo do foral de Évora, de 1166 o mouro é apresentado como mercadoria de compra e venda no mercado concelhio, independente de sexo ou idade. São áreas nas quais os centros possuem grandes alfozes envolventes e que era preciso explorar de uma forma bem controlada, sendo que a necessidade primeira era garantir o abastecimento de numerosa mão-de-obra barata.

Os conflitos deveriam ser evitados para que a população não migrasse ou fugisse, abandonando as herdades ou os ofícios citadinos. Para tanto, era necessária a manutenção da ordem, priorizando-se a Paz da Cidade43 através da ação do concelho representando a centralização régia em detrimento da justiça privada.

Os mouros eram aproveitados principalmente em atividades ditas urbanas, sendo procurados, pelos senhores cristãos, devido ao seu trabalho especializado. Eram

43 A Paz, 'coutada' pelo poder régio era uma das formas de conter os desmandos dos grandes senhores. Estava estabelecida por níveis de importância: primeiramente, havia a 'paz de el-Rei' onde se vedava qualquer tipo de violência onde se encontrava o rei e sua família ou nos caminhos por onde este passasse. Em seguida, havia a 'paz do concelho', onde estava proibida a violência no local da assembleia dos vizinhos. O mesmo valia para os demais locais de encontros e trocas sociais - a igreja e o mercado. Deviase proteger os locais públicos e quem neles habitassem e transitassem. Por fim, havia a 'paz da casa', uma forma de direito individual, que era exercida pelos vizinhos., que podiam assim oferecer o direito de asilo e refúgio contra os inimigos que porventura pudessem existir. Cf CAETANO, Marcello. Op cit, pg 255-257. 
artífices nas áreas de construção, dos curtumes, de calçados, na peliteria, ourivesaria e nos mesteres ligados à alimentação. Eram mercadores e almocreves, trazendo em suas bestas as mercadorias nos costais, sendo privilegiados com isenções:

Atestamos na verdade e para sempre firmamos que todo aquele que penhorar a mercadores ou viandantes cristãos, judeus ou mouros, a não ser o fiador ou devedor, todo aquele que fizer isto pague 60 soldos ao fisco [...] (FORAL DE PALMELA, 1185).

Os mouros cativos em razzias periódicas e nos fossados eram usados como moeda de troca, em resgate de cristãos em 'Terras de Mouros', tendo um preço estabelecido entre 30 e 100 morabitinos e esse comércio lucrativo era realizado pelos Alfaqueques.

Os muçulmanos residentes nos novos territórios portugueses passaram por períodos de grandes dificuldades, e a situação piorou ao extremo após 1150 (MARQUES; SERRÃO, 1986, p. 327-330), Só uma minoria permanecia nas antigas cidades e vilas antes islâmicas, agora vivendo em áreas fora das alcáçovas em bairros periféricos, por vezes denominados de Arrabaldes.

Entre estes, apenas uma pequena parcela, os membros da elite local e da sua aristocracia, teriam conseguido a manutenção de sua liberdade às custas da compra da alforria ou da carta de rendição.

Os monarcas posteriores (como D. Afonso III e D. Dinis) outorgarão às comunidades mouras do sul do Tejo os privilégios de 1170, devido ao crescimento das ditas comunidades, evitando o êxodo desta população mourisca para fora das povoações que tinham recebido estes privilégios.

E, também, para evitar os atritos e tensões nos concelhos cuja população majoritária cristã não parava de crescer, aumentando as distâncias socioeconômicas e causando animosidades desnecessárias e prejudiciais ao crescimento do reino.

Esse regime jurídico, baseado nos privilégios de 1170, estendidos para as demais comunas mouras, permaneceria estável até praticamente o fim do século XIV, revelando 
o peso que estas comunidades possuíam dentro das atividades concelhias, no que dizia respeito às estruturas de abastecimento dos mercados urbanos com produtos alimentares, em vestuário, calçados, ferragens, cerâmicas, tecelagens, cordoarias, vidro e vidraças entre outras.

Em 1179, D. Afonso Henriques concede um novo foral para a cidade de Lisboa, que passa a ser a 'força motriz' do pequeno reino lusitano, estendendo-se ao longo da orla marítima, afrontando seus inimigos a sul, leste e norte e, ao mesmo tempo, promovendo o desenvolvimento junto com as demais comunidades urbanas e camponesas que formavam a constelação lisboeta.

Estas coletividades que formavam o novo reino estavam centradas no concelho, que por sua vez agregavam os chefes militares/grandes senhores de terras, que possuíam casa e mulher, formando uma sociedade desigual: no cimo os cavaleiros vilãos e os cavaleiros do rico-homem que chefiava a guarnição militar, em segundo plano os peões e na base e fora do concelho, os braceiros, os mancebos, os míseros e os escravos.

Com a emissão dos forais, o poder régio favorecia as atividades da coletividade, e o concelho primava pela manutenção da lei e ordem de acordo com as obrigações e direitos estabelecidos, opondo-se à justiça privada senhorial e estabelecendo, assim, laços estreitos com $\mathrm{o}$ poder régio. $\mathrm{E}$ forçavam as comunidades subjugadas a dependência direta e exclusiva como forma de sua própria existência.

A situação do mouro nos sécs. XII e XIV é bastante multifacetada, na qual podemos perceber algumas tendências gerais. O estabelecimento da 'tutela régia' sobre a população muçulmana não impediu que os senhores, os concelhos e particulares tentassem se beneficiar desta mão-de-obra.

Com o estabelecimento de um estatuto jurídico para estas comunidades muçulmanas a partir do Foral de 1170, organizava-se então a comuna moura, que poderia ser urbana ou rural, de acordo com a sua inserção socioeconômica no seio da sociedade citadina.

As mourarias diferenciavam-se então pela importância dos seus residentes (ligados ou não ao poder, como antiga elite conquistada), pelo nível de riqueza e papel 
de suas atividades mesteirais, o que se expressava na divisão na comuna entre a aristocracia que vivia em áreas mais ricas (parte alta) e a população mais pobre, ligada aos ofícios menores que viviam nas áreas mais simples ou nos termos (parte baixa).

As mourarias urbanas em Portugal medievo centravam-se em 16 comunas urbanas: no Norte do Tejo (Leiria, Santarém, Alenquer, Lisboa e Colares), ao sul do Tejo (Setúbal, Alcácer do Sal, Avis, Elvas, Estremoz, Évora, Moura e Beja), e no Algarve (Silves, Loulé, Tavira e Faro). ${ }^{44}$

Os conceitos de comuna e, de mouraria são passíveis tanto de diferenciação quanto de justaposição de acordo com o contexto ao qual se referem. A mouraria seria o espaço físico no qual habitavam os mouros, qual um bairro árabe, e a comuna o conjunto de todos os seus órgãos (religiosos, administrativos e legais) que permitem a tal grupo, a partir da mercê régia, manter uma identidade própria no interior da sociedade cristã, ainda que se sujeitando à legislação do reino (BARROS, 1998, p. 20-31).

A comuna permitiria, então, que se equacionasse o relacionamento da minoria muçulmana com a sociedade circundante, expressando assim uma diferenciação cultural que justificava a sua preservação ao conjugar o espaço físico com a sua organização jurídico-administrativa.

Pelo Foral de 1170 , as comunidades tinham a garantia de tolerância religiosa, o direito de eleger seus oficiais de justiça, além da manutenção de suas leis e costumes em questões de foro interno: "[...] assy que em minha Terra nenhum mal, e sem razom nom recebades, e que nenhuum chrisptãao, nem judeu sobre vos aja poder de vos empeecer, mais aquelle, que vós da gente e fé vossa sobre vós". ${ }^{45}$

\footnotetext{
${ }^{44}$ As mourarias urbanas foram mais documentadas devido principalmente a sua inserção no seio citadino, já que os mouros exerciam as mais variadas atividades ligadas aos mesteres. As comunas mouras rurais, também muito importantes, tiveram uma ocorrência menor mas não menos importantes, visto serem utilizadas principalmente pelo poder régio como forma de ocupação de novas terras, após a reestruturação sócio-política pós-reconquista, isso após a Segunda metade do século XII.
}

${ }^{45}$ Foral dos Mouros Forros de Lisboa, Almada, Palmela e Alcácer, 1170. PMH Pg.396-397. 
A comuna, coincidindo com a sua delimitação física - a mouraria - permitia aos

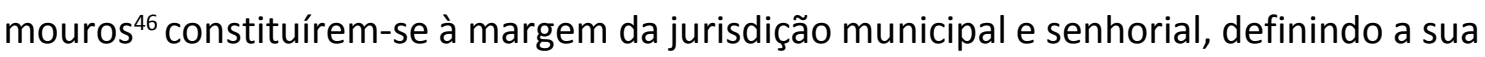
permanência em função dos vetores de sua diferenciação, já que são parte do tecido social que compõem o concelho, e de sua segregação em relação à sociedade cristã circundante.

A carta consagrava o seu estatuto jurídico como comuna moura, impondo-lhes determinadas obrigações coletivas que deveriam ser satisfeitas por todos e por cada um de seus membros.

Assim, incidia sobre os indivíduos adultos e os adolescentes capazes de ganhar o seu próprio sustento, o imposto anual 'per capita', que consistia no pagamento de 1 morabitino. Já a al-fitra era um imposto que deveria ser pago por todos os membros da comuna, desde o nascimento e seu valor era de 6 dinheiros. O mais importante, o $a z$ zaqui, era uma contribuição predial que deveria ser paga por todos os haveres do contribuinte, equivalendo a um total de $2,5 \%$ do montante daqueles. Este imposto se desdobrava em outros menores, e era a mais expressiva forma de contribuição dos elementos da comuna para o erário régio. Os membros da comuna deviam ainda dar a dízima ao rei de todos os rendimentos de seu trabalho e fazer as jeiras, vendendo ainda o figo, o azeite e o vinho régios.

O foral de 1170 mais tarde estendido para outras comunas mouras (Faro, Loulé, Tavira e Silves, em 1269; Évora, em 1273; Moura, em 1296), revela o peso que estas comunidades mudéjares possuíam no desenvolvimento das estruturas de abastecimento dos mercados urbanos concelhios, no comércio e ofícios principalmente, e o mais importante: deviam a casa senhorial régia, impostos específicos, além de atribuições particulares como a venda de seus vinhos, azeite e figos. ${ }^{47}$

\footnotetext{
${ }^{46}$ Os termos referentes aos muçulmanos eram os mais variados: mouros quando designavam servos ou escravos, mouros forros quando se referiam aos membros da elite ou com cabedal, muladis ou os conversos ao Islã, mouriscos quando eram convertidos ao cristianismo; mudéjar significando vassalo, ou estatuto similar. O mais comum era o termo mouro, independentemente de sua etnia pois era uma diferenciação religiosa em contraponto ao cristão.

${ }^{47}$ Desde século XIII, há uma grande preocupação em usar os mouros cativos nos fossados/azarias como forma de troca por cristãos aprisionados/escravizados em Terra de Mouros. Os cativos mouros eram negociados então pelos Alfaqueques e pela ação das ordens e casas conventuais, como os Trinitários
} 
Com o estabelecimento da comuna e a submissão dos mouros como servos diretos do poder régio, criou-se uma 'jurisprudência de controle' (BARROS, 1998) que se impôs às estruturas comunais, pois os mouros deviam servir exclusivamente ao rei, em seus reguengos ou em ofícios especializados.

Por isso, D. Afonso III, preocupado com a possibilidade de perder seus servos na região, reafirma, em 1269 e 1273, para as comunas de Évora, Silves, Loulé, Faro e Tavira os privilégios do Foral dos Mouros Forros de $1170 .{ }^{48}$

As principais mourarias, de maior peso, como grandes centros urbanos eram as comunas de Lisboa e Santarém, tendo como parte de sua área de influência as mourarias da península sadina, por estarem próximas aos melhores portos marítimos e fluviais.

A carta de privilégios de 1170 exprime um discurso oficial que submete os muçulmanos conquistados a um poder que se intitula legítimo e que busca reorganizar o espaço conquistado. O rei procura, então, respeitar a organização islâmica das comunidades, a partir da nova realidade como conquistados, instituindo-se como seu protetor, onde a proteção regia é uma forma de obtenção de serviços específicos e únicos, destinados a casa real.

Os muçulmanos de condição social inferior eram, em sua maior parte, reduzidos ao estatuto de cativos de guerra, indo com isso abastecer os florescentes mercados de escravos $^{49}$ nos centros urbanos setentrionais.

(ordem da Santíssima Trindade) ou os Mercedários (ordem de Santa Maria da Mercê). As ordens militaresreligiosas também atuaram na remissão dos cativos, fundando para isso Hospitais, como o Hospital de São Miguel, fundado em Évora (1214) pelos freires de Évora. Cf MARQUES, A. H. de Oliveira \& SERRÃO, Joel. (Dir.). Op cit, pag. 337-340.

48 ' [...] facio cartam de foro et firmitudine uobis Mauris qui estis fori in Silue et in Tauira et in Loule et in sancta Maria de Faaron [...] et in omnibus aliis debetis facere et usare sicut usant et facient mei mauri forri ulixbone [...]. Foral dos Mouros Forros de Silves, Tavira, Loulé e Santa Maria do Faro, 1269. PMH s.d.

${ }^{49}$ Os escravos ou servos muçulmanos eram usados principalmente pelas famílias populares ou nobiliárquicas enriquecidas, e pelos senhorios eclesiásticos. Basicamente associados aos animais de tiro, os mouros faziam então os serviços domésticos e demais trabalhos de cultivo nas reservas senhoriais. Cf MARQUES, A H. de Oliveira \& SERRÃO, Joel (Dir.). Op cit Pg 312-316. 
O foral lisboeta estipulava ainda as coimas ${ }^{50}$ que deveriam ser pagas de acordo com os delitos cometidos, com destaque para os roubos, raptos, estupros, homicídios, violências diversas, furto e violação de domicílio

As coimas mais pesadas do foral lisboeta, que serviria de modelo àqueles outorgados a Tavira, Loulé, Faro (Santa Maria do Faro) e Almada (1190) ${ }^{51}$ como forma de equilibrar as inter-relações entre a população cristã e as comunas mouras aí estabelecidas., relacionavam-se ao uso da violência, demonstrando que a cidade ainda deveria ser ordenada social e politicamente, neste momento pós-reconquista principalmente.

Almada, Tavira, Loulé e Santa Maria do Faro eram áreas reconquistadas onde havia comunas mouras ou mourarias de relevada importância econômica, ou ainda, no caso de Almada, Palmela e Alcácer, castelos e praças-fortes necessárias para promover a defesa da linha do Tejo e o monopólio do estuário do Sado, impedindo, assim, a perda dessas para os muçulmanos.

Os conflitos nesta região deveriam ser evitados para que a população não migrasse ou fugisse, abandonando as herdades ou os ofícios citadinos. A prioridade concelhia era garantir seu crescimento a partir do recolhimento das taxas e impostos devidos pela circulação dos produtos, dos serviços e dos homens. O comércio era então estimulado, trazendo para a cidade os maravedis que sustentavam, inclusive, o processo de centralização régia, já que o palácio recebia boa parte das taxas. Isso ocorria com o grupo dos forais que se originam do foral de Évora, como é o caso de Palmela (1185), de Alcácer (1218) e Sesimbra (1201), onde havia comunas mouras pós-reconquista. No foral de Palmela, castelo reconquistado e base da ofensiva das correrias cristãs ao sul do Tejo, vemos que na maior parte das coimas o rei recebia a sua sétima parte pelo fisco, sendo seu representante o juiz:

Damos a vós foro e costume de Évora quer no presente como no futuro para que duas partes dos cavaleiros vão ao fossado, e uma Terça parte fique no

\footnotetext{
${ }^{50}$ A coima ou a calumnia era uma multa criminal, que deveria ser paga ao rei ou ao senhorio ou aos ofendidos. Cf CAETANO, Marcello. Op cit, Pg. 250.

${ }^{51}$ Estes forais não possuem a data do recebimento de seus diplomas na $\mathrm{PMH}$.
} 
castelo: e uma vez por ano façam fossado. E quem não for ao fossado pague pelo foro 5 soldos para a fossadaria. [...]E por todas as causas do fisco o juiz seja o vozeiro (FORAL DE PALMELA, 1185).

Segundo o costume de Évora, o foral palmelense priorizava o estabelecimento e a fixação da população, isentando-a de alguns tributos ligados às atividades militares ${ }^{52}$ à produção agrícola, caça, atividades mesteirais (lojas e tendas de comércio), moinhos e fornos.

Palmela, por ser cidade fronteiriça, praça forte, centro de difusão comercial em constante contato com o mundo islâmico, a segurança e a ordem deveriam ser mantidas a todo custo, para que o concelho crescesse e, assim, manter a exploração servil sobre as populações mouras subjugadas e que conviviam diretamente com o concelho, cristão.

Os monarcas posteriores aos primeiros reis da reconquista (como D. Afonso III e D. Dinis) outorgariam às comunidades mouras do sul do Tejo os privilégios de 1170 devido ao crescimento delas, com o intuito de evitar o êxodo da população mourisca destas povoações, além dos atritos e tensões nos concelhos cuja população, majoritariamente cristã, não parava de crescer, aumentando as distâncias socioeconômicas e causando animosidades desnecessárias e prejudiciais ao crescimento do reino.

E entre todos estes mesteres, aí estava o braço do servo mouro a laborar nos campos ou nas tendas dos artífices, sendo moeda de troca ou simplesmente mais um a percorrer as vielas e ruas principais da cidade a apregoar os seus produtos, tendo seu estatuto de servo régio sofrido mudanças significativas o suficiente para que ele seja agora, do século XII em diante, sobretaxado pelo concelho onde se insere.

Com o foral de 1170, a comuna moura de Lisboa tornou-se o modelo paradigmático para a constituição das demais aljamas no reino. Os antigos privilégios dados pelos primeiros monarcas foram reafirmados nas cartas de 1269 e 1273, mas de

\footnotetext{
52 Damos a vós foro e costume de Évora quer no presente como no futuro para que duas partes dos cavaleiros vão ao fossado, e uma Terça parte fique no castelo: e uma vez por ano façam fossado. E quem não for ao fossado pague pelo foro 5 soldos para a fossadaria”. In: Foral de Palmela, 1185. PMH.
} 
forma a evitar que a população moura já estabelecida entrasse em choque com os concelhos.

O muçulmano ia sendo assimilado, na condição de 'outro', pela maioria da população cristã com a qual conviveu ao longo do Trezentos, a despeito das divergências de interesses entre a comuna e o concelho, já que para os muçulmanos os seus direitos adquiridos conforme mouros e 'mudéjares' seriam irrevogáveis e, para os cristãos estes direitos seriam 'mercê gratuita', passível de anulação régia a qualquer momento.

Até o século XIV, a ideologia trinitária impera como forma de promover o controle e o 'sacramento' de uma unidade, na qual o Rei deveria exercer uma jurisdição social como forma de manutenção da hierarquia, o que se transformou nos séculos XIV e XV. Nos séculos XIV e XV, a ideologia das Três Ordens passou a ser um referencial teórico e jurídico, sendo utilizado como forma de subordinar principalmente o terceiro segmento da sociedade, o 'povo'.

Para a manutenção da sociedade ordenada, o poder régio deveria 'domesticar' os seus membros através da legislação, já que o direito era o principal meio ordenador das relações sociais. Este instrumento de controle social, especialmente utilizado pelo poder régio centralizador, consistia de regras coercitivas e sanções referendadas pelas Cortes e aplicadas pelo seu aparato judicial. E visava, antes de mais nada, a imposição de modelos comportamentais, de forma a enquadrar os indivíduos em uma determinada ideia de comunidade, instituindo, assim, a identidade de grupo, seja pela diferenciação ou mesmo pela exclusão.

Este processo se fortaleceu nos séculos XIV e XV, com a intensificação da ligação dos legistas com os reis (primeiramente, sob D. Afonso III e, em seguida, sob D. Dinis) possibilitando o surgimento do arcabouço jurídico do Estado, cuja estruturação tem lugar preponderantemente no decorrer do século XV. Com D. Afonso III e D. Dinis, impõe-se a primazia do direito civil, lançando as bases para uma ordem jurídica nacional dirigida e tutelada pelo poder régio, possibilitando cada vez mais a ascendência de um direito comum em detrimento dos direitos próprios ou particulares. 
Assim, os reis subsequentes vão impondo a unidade, a centralização e a manutenção da ordem ao conjunto da população é forjada, pouco a pouco, com apoio do direito civil, a ideia de pertencimento, um referencial integrador para esta sociedade em mudança. Neste sentido, como afirma Sousa (SOUSA, 2002, p. 367-371) a terra juntamente com o rei e a Igreja, formam os vértices restantes do triângulo de significação que dá a ideia de pertencimento, faz surgir um novo modelo identitário português no qual se manifestam os conceitos de diferenciação entre os 'portugueses' e os 'outros'.

Estes "outros" podem ser os castelhanos, os estrangeiros que circulam pelo reino como comerciantes ou viandantes ou, então, os 'portugueses não cristãos', entre os quais se inserem mouros, judeus, negros escravizados nas campanhas marroquinas, sendo vistos como portugueses de 'segunda'.

No século XV, com a centralização régia fortalecida, desponta uma sociedade que se representa como constituída por ordens, contudo, em sua vivência cotidiana nas Cortes, o que se detecta são estados que se manifestam politicamente e deixam transparecer o quanto esta nova sociedade é pluripartida, o que também é visível nas procissões de Corpus Christi, símbolo da união citadina e de pertencimento à lógica cristã, e nas comemorações régias.

A estruturação da sociedade em 'estados' tem como foco primordial a característica socioprofissional, cujos valores surgem a partir do renascimento urbano, com a divisão e especialização das atividades produtivas, e a afirmação de uma certa 'burguesia' comercial, entre outras. Há com isso um choque de mentalidades, pois para a nobreza ainda presa à sociedade de ordens, deve-se externar o estado ao qual pertence, a sua honra apesar da riqueza. Agora, para os mesteirais, grande comerciantes ou até mesmo para as gentes simples do povo, ser rico era ter acesso a fidalguia, era ser considerado honrado, bom, ter qualidades o suficiente para que o seu nome pudesse compor os pelouros e obter privilégios régios Havia ainda as designações de estados situações, formulação de caráter jurídica, fornecendo mais especificamente um relato da situação dos estados a nível judicial, administrativo, econômico, criminal de uma determinada localidade, como forma de maior controle do poder régio, através de suas 
instituições. Já os estados - situações seriam a forma hierarquia partir daí, qual era o lugar e a função do mouro nestes estados? Como ele se insere nesta formulação identitária, e como se dá a formulação de sua própria identidade enquanto membro pertencente do corpo citadino e do corpo do Reino?

O mouro é visto, assim, através da legislação régia, desde o momento pósreconquista, pelo estatuto de servo régio, sendo a sua liberdade é condicionada aos seus direitos e deveres como dependentes de determinadas carreiras, como os eclesiásticos e os militares. Mas agora, no século XV, também é visto como súdito, conforme os demais vassalos do Rei, pagando então seus impostos duplamente: os tributos enquanto mouros e os demais encargos como o restante da população, pois ser vassalo significava também o pagamento dos tributos para o erário régio e, os prestamos ao rei quando este necessitasse.

Com o direito canônico, o mouro passa a ser visto não apenas como o 'infiel', mas também como 'inimigos da santa fé', acarretando maiores conflitos na sociedade medieva cristã, o que acarretará mais tarde em atitudes extremas como a imposição dos símbolos da infâmia e demais restrições culturais, que culminarão, no fim do século XV, em sua expulsão do reino.

\section{Referências}

\section{Documentação}

CHANCELARIAS PORTUGUESAS - D. AFONSO IV (1325-1357). 4 vol. Ed. De A. H. de Oliveira Marques. LiSBOA: INIC, 1990.

CHANCELARIAS PORTUGUESAS - D. DUARTE (1433-1435).4 vol. Ed. De A. H. de Oliveira Marques. LiSBOA: INIC, 1990.

FORAIS: 'Foral dos Mouros Forros de Lisboa, Almada, Palmela e Alcácer de 1170'; 'Foral de Lisboa de 1179'; 'Foral de Palmela de 1185'; 'Foral de almada de 1190'; 'Foral de Sesimbra de 1201'; 'Foral de Alcácer de 1218'; 'Foral dos Mouros Foros de Silves, Tavira, Loulé e Santa maria do Faro de 1269'; 'Foral dos Mouros Forros de Evora de 1273'. Encontram-se publicados na Portugaliae Monumenta Historica. Vol II. Leges et Consuetudines. Ed. De Alexandre Herculano. Lisboa: 1868. 
LIVRO DAS LEIS E POSTURAS DA CIDADE DE LISBOA. Ed. De Maria Teresa Campos Rodrigues. Lisboa: faculdade de Direito, 1971.

ORDENAÇÕES AFONSINAS (Livros I e II). Reprodução fac símile da edição feita na real Imprensa da Universidade de Coimbra em 1792. Lisboa: Fundação Calouste Gulbenkian, s.d.

ORDENAÇÕES DEL REI D. DUARTE. Ed. De martim de Albuquerque e Eduardo Borges Nunes. Lisboa: Fundação Calouste Gulbenkian, 1988 REIS, Antonio Matos. A Origem dos Municípios Portugueses. Lisboa: Livros Horizonte,2002.

\section{Bibliografia}

ARMSTRONG, Karen. O Islã. Rio de Janeiro: Objetiva, 2001. . Maomé - uma Biografia do Profeta. São Paulo: Companhia das letras, 2002.

BARROS, Maria Filomena Lopes de. A Comuna Muçulmana de Lisboa - Sécs. XIV e XV. Vol.4. Biblioteca de Estudos Árabes. Lisboa: Editora Hugin, 1998.

BERNARDO, João. Poder e Dinheiro. Do Poder Pessoal ao Estado Impessoal no Regime Senhorial, Séculos V-XV. Parte I. Porto: Edições Afrontamento, 1995.

BOSSY, J. A Cristandade no Ocidente (1400-1700). Lisboa: Edições 70, 1985.

EL HAYEK, Samir. Os Significados dos Versículos do Alcorão Sagrado com comentários. 18a Edição, São Paulo: FAMBRAS, 2016.

CAETANO, M. A Administração Municipal de Lisboa Durante a $1^{\underline{a}}$ Dinastia (1179-1383). Lisboa :Academia Portuguesa de História, 1981.

CAETANO, Marcello. História do Direito Português (Sécs.XII-XVI) - Subsídios para a História das Fontes do Direito em Portugal no Século XVI. Lisboa/São Paulo: Editorial Verbo,2000.

CARVALHO, Sergio Luis de. As Cidades Medievais Portuguesas. Uma Introdução ao seu estudo. Lisboa: livros Horizonte, 1989.16

COELHO, Antonio Borges. Questionar a História - ensaios sobre a História de Portugal. Lisboa: Editorial Caminho. Coleção Universitária, 1986. 
Lisboa: Editorial Caminho, 1989.

Portugal na Espanha Árabe. Vol 1. Geografia e Cultura.

COSTA, Mário Júlio de Almeida. História do Direito Português. Coimbra: Livraria Almedina, 2002 CUNHA, Andrea Alvares da. 'Aos meus mouros forros de Lixboa'. Identidade, dependência e hierarquia nas comunidades muçulmanas do reino de Portugal (séculos XII ao XV). Dissertação de mestrado apresentada ao curso de Pós graduação em História da Universidade Federal Fluminense, Rio de Janeiro, Niteroi, 2005.

- O rei cristão e o estatuto social dos Mouros Forros de

Palmela (1170-1185) TCC, Niterói, Universidade Federal Fluminesne, 2000.

GOMES, Pinharanda. A Filosofia Arabigo-Portuguesa. In História da Filosofia Portuguesa. Vol.3.Lisboa: Guimarães Editores, 1991.

HEERS, J. Escravos e Domésticos na Idade Média. São Paulo : DIFEL, 1983, P.23-24.

LE GOFF, Jacques \& SCHMITT, Jean Claude (Coord). Dicionário Temático do Ocidente Medieval. Coord da tradução Hilario Franco Junior. Bauru, SP: EDUSC; São Paulo, SP: Imprensa Oficial do Estado, 2002, 2 vol.

LEWIS, Bernard. A linguagem política do Islão. Coleção Aldeia Global. Lisboa: Edições Colibri, 2001.

LIVRO DE CORTES PORTUGUESAS - REINADO DE D. AFONSO IV (1325-1357). Ed. De A. H. de Oliveira Marques, Maria Teresa campos Rodrigues, Nuno José Pizarro Pinto Dias. Lisboa: INIC, 1982.

LOYN, H. N. Dicionário da Idade Média. Rio de janeiro: Jorge zahar editor, 1990.

MACEDO, Jose Rivair. Os sinais da infâmia e o vestuário dos mouros em Portugal nos séculos XIV e XV. Trabalho apresentado no Ateliers franco-latino-americains II (argentine-Brésil-France). Le Moyen Age um d'ailleurs, São Paulo: USP, agosto de 2003.

MANTRAND, Robert (Dir). As grandes datas do Islão. Biblioteca de História. Lisboa: Editorial Notícias, 1990.

MARQUES, A.H.O. \& SERRÃO, J. (Dir.) Nova História de Portugal - Portugal em Definição de Fronteiras (1096-1325). Vol.III. Lisboa: Editorial Estampa, 1986.

MARQUES, A. H. de Oliveira. Guia do Estudante de História Medieval Portuguesa. Lisboa: Editorial Estampa, 1988.

MARQUES, A. H. de. A Sociedade Medieval Portuguesa. Lisboa:Ed. Sá da Costa, 1981. 
Presença, 1988.

Novos Ensaios de História Medieval Portuguesa. Lisboa: Editorial

MATTOSO, José. Fragmentos de uma composição Medieval. Lisboa: Editorial Estampa, 1986.

SERRÃO, Joel (Dir). Dicionário de História de Portugal. Lisboa: Iniciativas Editoriais, 19611971. 4 vols.

SOUSA, Armindo de. A Sociedade - estruturas, grupos e motivações. In: MATTOSO, Jose. História de Portugal - A Monarquia Feudal (1096-1480). Lisboa: Editorial Estampa, 1993.

VASCONCELLOS, Jose Leite de. Etnografia Portuguesa.vol.II. Lisboa: Imprensa Nacional, 1958.

ZAIDAN, A. K. O indivíduo e o estado no Islam. São Paulo: CDIAL, 1990. 